\title{
Spatial analysis for the epidemiological study of cardiovascular diseases: A systematic literature search
}

\author{
Carlos Mena, ${ }^{1}$ Cesar Sepúlveda, ${ }^{2}$ Eduardo Fuentes, ${ }^{2,3}$ Yony Ormazábal, ${ }^{1}$ Iván Palomo ${ }^{2}$ \\ ${ }^{1}$ Geomatics Centre, Faculty of Forestry Sciences; ${ }^{2}$ Thrombosis Research Center, Department of Clinical \\ Biochemistry and Immunohematology, Faculty of Health Sciences, Interdisciplinary Excellence Research \\ Program on Healthy Aging (PIEI-ES); ${ }^{3}$ Multidisciplinary Scientific Nucleus, University of Talca, Chile
}

\begin{abstract}
Cardiovascular diseases (CVDs) are the primary cause of death and disability in de world, and the detection of populations at risk as well as localization of vulnerable areas is essential for adequate epidemiological management. Techniques developed for spatial analysis, among them geographical information systems and spatial statistics, such as cluster detection and spatial correlation, are useful for the study of the distribution of the CVDs. These techniques, enabling recognition of events at different geographical levels of study (e.g., rural, deprived neighbourhoods, etc.), make it possible to relate CVDs to factors present in the immediate environment. The systemic literature presented here shows that this group of diseases is clustered with regard to incidence, mortality and hospitalization as well as obesity, smoking, increased glycated haemoglobin levels, hypertension physical activity and age. In addition, acquired variables such as income, residency (rural or urban) and education, contribute to CVD clustering. Both local cluster detection and spatial regression techniques give statistical weight to the findings providing valuable information that can influence response mechanisms in the health services by indicating locations in need of intervention and assignment of available resources.
\end{abstract}

Correspondence: Carlos Mena, Centro de Geomática, Universidad de Talca, Lircay SN, 07101 Talca, Chile.

Tel.: +56.71 .2200442 .

E-mail: cmena@utalca.cl

Key words: Spatial analysis; Cluster; Cardiovascular diseases.

Contributions: the authors contributed equally.

Conflict of interest: the authors declare no potential conflict of interest.

Funding: this work was also funded by Interdisciplinary Excellence Research Program on Healthy Aging (PIEI-ES).

Received for publication: 23 May 2017.

Revision received: 6 December 2017.

Accepted for publication: 10 January 2018.

CCopyright C. Mena et al., 2018

Licensee PAGEPress, Italy

Geospatial Health 2018; 13:587

doi:10.4081/gh.2018.587

This article is distributed under the terms of the Creative Commons Attribution Noncommercial License (CC BY-NC 4.0) which permits any noncommercial use, distribution, and reproduction in any medium, provided the original author(s) and source are credited.

\section{Introduction}

In recent years, the application of spatial analysis has gained relevance in epidemiological identification and management of factors associated with disease (Graham et al., 2004; Rezaeian, 2009). Most of these studies rely on spatial statistics to reveal related factors, which therefore play an important role in simplifying decision making, application of interventions and distribution of resources. Although these techniques are particularly useful for infections requiring vectors (Anno et al., 2015; Bergquist, 2017) they have been shown to also be helpful in the study of cardiovascular diseases (CVDs) and other non-communicable disorders (Olveira et al., 2015; Park et al., 2016; Martínez-Bascuñán and Rojas-Quezada, 2017). Geospatial studies use different techniques to establish correlations, some of which can be complex and difficult to explain to the non-specialist, while the outcome, e.g. a map, can visualize epidemiological situations that can be immediately grasped by the layman. In this type of studies different concepts are used that are worth recognizing. Indeed, different spatial techniques are useful at different levels and they are complementary to each other.

Mapping is a useful approach to empirically identify events associated with health. These results must, however, be carefully interpreted according the geographical units selected considering the many possible variables at hand. For example, deprivation indices are typically designed for small geographic areas (e.g. neighbourhoods), while approaches used when mapping larger administrative areas, such as district or regions, are likely to mask pockets of deprived neighbourhoods (Exeter et al., 2007, 2014). When attempting toconnect health data with an area, it is important to consider geographical units corresponding to the area level chosen for the analysis, e.g., subdividing a large territory such as a city, into small, not overlapping representative units (GómezRubio et al., 2005). It is also important to choose an area of appropriate size, as very large areas could hide information of interest, while small areas are generally not only homogeneous but also more transparent (Rezaeian et al., 2006; Tonne et al., 2009). Spatially analyses usually use subdivisions which are also administrative units, such as census tracts, census block groups or they use the mail delivery system, i.e. ZIP codes (Osypuk and Galea, 2007; Arsenault et al., 2013). Naturally, the study area can also be defined arbitrarily (Zhu et al., 2012). For cluster determinations, the required data are the occurring number of events of interest, the expected number of events and the population at risk in each spatial unit of a specific territory (Gómez-Rubio et al., 2005). In addition, it is possible to subdivide this information into various strata (personal such as sex, age, income, etc.) or the general economic strength of each region under study (Gómez-Rubio et al., 2005). Cluster detection is an important epidemiological tool because it can help identifying factors associated with disease. It corresponds to a set of events that are spatially closely related. Positive spatial autocorrelation (SA) 
implies that the rates for a given phenomenon tend to be similar for neighbouring areas in comparison to those that are geographically distant (Griffith, 1987; Rezaeian et al., 2007). For example, health variables and underlying related factors trend to be spatially correlated (Lorant et al., 2001; Sofianopoulou et al., 2006), which is due to the high probability that closely situated areas have similar underlying factors related to various phenomena (Rezaeian et al., 2007). It should, in this connection be recognized that there is a difference between the global and the local situation. While the focus when searching for global clusters is on their existence, not location (Aamodt et al., 2006; Jacquez, 2008), local cluster analysis aims at quantifying SA and clustering in small geographical units within the study area (Jacquez, 2008). Moran's $I$ is a commonly used spatial statistic for the detection of global clustering (Moran, 1948), with local indicators of spatial association (LISA) being the statistic of choice for finding local clustering (Anselin, 1995, Bailey and Gatrell, 1995) allowing decomposition of the indicators. Other techniques used for the detection of local clusters are the GetisOrd Gi static (1992), the geographical analysis machine (Openshaw et al., 1987) and spatial scan statistic (Kulldorff, 1997). Regression techniques are used to determine possible correlations between variables of interest and give information about direction and strength of the relation. A more simple way to assay correlations between variables is to determine the dependent variable and adjust for other possible explanatory factors suggesting evidence for causal association (Jerrett et al., 2003). Others techniques used for estimating spatial regression are ordinary least squares (OLS) (Ford and Highfield, 2016), geographically weighted regression (GWR) (Brunsdon et al., 1996), bivariate LISA (de Andrade et al., 2013; Martinez et al., 2014), the generalized additive model (Hastie and Tibshirani, 1986) and the spatial lag model (Levine et al., 1995). The present research was undertaken to highlight the application of geospatial analysis for the recognition of factors that determines the spatial distribution of CVD in addition to recognizing the utility of these techniques for the allocation of resources and generation of public policies for CVD.

\section{Materials and Methods}

A systematic literature search covering the latest decade of geospatial studies involving CVD was undertaken to investigate the current use spatial statistics and provide an up-to-date overview of this field. PubMed (https://www.ncbi.nlm.nih.gov/pubmed/) and ScienceDirect (https://www.sciencedirect.com/), the two major databases providing access to scientific and medical research, were searched using the following key words: CVD and infarct; CVD and spatial analysis; and CVD and cluster. Inclusion criteria were the following: title or abstract of papers recognizing the use of spatial techniques (including mapping, cluster detection and spatial regression); focus on spatial, ecological studies (since the search term CVD and spatial analysis also yielded results on imaging techniques used for diagnosis that was outside our interest); articles published in the last decade. Exclusion criteria: review articles, work prior to 2007 and articles without abstracts.

\section{Results and Discussion}

The territorial distribution of the CVDs is not homogeneous. Publications based on the spatial occurrence of CVD show that this group of diseases is clustered with regard to parameters, such as incidence (Kjaerulff et al., 2016), mortality (de Andrade et al., 2013; Gohari et al., 2015; Gomez-Barroso et al., 2015; van Rheenen et al., 2015; Roberson et al., 2016) and hospitalization (Soares and Nascimento, 2010; Roberson et al., 2016). Likewise, factors directly related to CVD, obesity as measured by the body mass index (BMI) (Mobley et al., 2004; Tamura et al., 2014), smoking (Mobley et al., 2004), increased glycated haemoglobin (HbA1c) levels (Jiwa et al., 2015; Paquet et al., 2016), hypertension (Wang et al., 2014b) and physical activity (Tamura et al., 2014; Cunningham-Myrie et al., 2015) also tend to cluster. These factors and others, like age, income, residency (rural or urban) and education, contribute to CVD clustering (Talbott et al., 2013; Nunes et al., 2013; Ahmadi et al., 2015; Caswell, 2016). Spatial analysis facilitates the study of the distribution on factors related to CVD from a spatial, seasonal or temporal viewpoint (Wang et al., 2014a; Roberson et al., 2016). These studies are not only useful, but indeed necessary, since an adequate space-time interpretation of factors involved with a disease allows suitable designation of priorities, resource distribution and policy implementation. Tables 1 and 2 summarize recent studies for cluster detection and spatial correlation with regard to the CVDs.

Table 1. Recent general cardiovascular disease (CVD) studies based on cluster detection and spatial correlation.

\begin{tabular}{|c|c|c|c|c|c|}
\hline Place & Level of study & Cluster detection & Spatial correlation & Main findings & Reference \\
\hline $\begin{array}{l}\text { State of Paranà, } \\
\text { Brazil }\end{array}$ & City & $\begin{array}{l}\text { GCD by Moran's I } \\
\text { LCD }{ }^{\mathrm{b}} \text { by LISA }\end{array}$ & Bivariate Moran's I & $\begin{array}{l}\text { IHDc clusters positively correlated with } \\
\text { old age, illiteracy and urban development }\end{array}$ & $\begin{array}{l}\text { de Andrade et al., } \\
2013\end{array}$ \\
\hline Madrid, Spain & Census tract & $\begin{array}{l}\text { GCD by Moran's I } \\
\text { LCD by LISA }\end{array}$ & Not done & $\begin{array}{l}\text { Clustered CVD leading to death } \\
\text { (men and women) }\end{array}$ & $\begin{array}{l}\text { Gomez-Barroso } \\
\text { et al., } 2015\end{array}$ \\
\hline Alberta, Canada & $\begin{array}{l}\text { Provincial health } \\
\text { care network }\end{array}$ & $\begin{array}{l}\mathrm{LCD}^{\mathrm{b}} \text { by Getis-Ord Gi } \\
\text { and spatial scan statistics }\end{array}$ & Not done & $\begin{array}{l}\text { Regional disparities in spatial } \\
\text { distribution of stroke; clusters } \\
\text { of stroke and stroke risk were not } \\
\text { spatially associated }\end{array}$ & $\begin{array}{l}\text { van Rheenen } \\
\text { et al., } 2015\end{array}$ \\
\hline Florida, USA & County & $\begin{array}{l}\text { GCD by Moran's I } \\
\text { LCD by LISA }\end{array}$ & Not done & $\begin{array}{l}\text { Clusters of stroke resulting in } \\
\text { hospitalization or death }\end{array}$ & $\begin{array}{l}\text { Roberson et al., } \\
2016\end{array}$ \\
\hline $\begin{array}{l}\text { Vale do Paraiba, } \\
\text { Brazil }\end{array}$ & Municipality & $\begin{array}{l}\mathrm{GCD}^{\mathrm{a}} \text { by Moran's I } \\
\text { LCD by LISA }\end{array}$ & Not done & Clusters of $\mathrm{AMI}^{\mathrm{d}}$ and hospitalization & $\begin{array}{l}\text { Soares and } \\
\text { Nascimento, } 2010\end{array}$ \\
\hline Tehran, Iran & County & $\begin{array}{l}\text { LCD }^{\mathrm{b}} \text { by Spatial Scan } \\
\text { statistics }\end{array}$ & Not done & $\begin{array}{l}\text { Clusters of death due to acute heart } \\
\text { disease, cerebrovascular disease } \\
\text { and hypertension }\end{array}$ & Gohari et al., 2015 \\
\hline
\end{tabular}

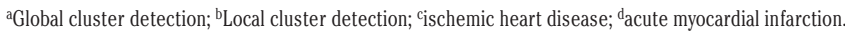


Table 2. Recent specific cardiovascular disease (CVD) studies based on cluster detection and spatial correlation.

\begin{tabular}{|c|c|c|c|c|c|c|}
\hline Related variable & Place & $\begin{array}{l}\text { Level } \\
\text { of study }\end{array}$ & $\begin{array}{l}\text { Cluster } \\
\text { detection }\end{array}$ & $\begin{array}{l}\text { Spatial } \\
\text { correlation }\end{array}$ & Main findings & Reference \\
\hline \multirow[t]{5}{*}{ Socio-economic status } & Harris, USA & Census tract & GCD by Moran's I & OLSc and GWR ${ }^{\mathrm{d}}$ & $\begin{array}{l}\text { Spatial cluster of } \\
\text { high CVD mortality } \\
\text { associated with social } \\
\text { deprivation according } \\
\text { to GWR (better fit than OLS) }\end{array}$ & $\begin{array}{l}\text { Ford } \\
\text { and Highfield, } \\
2016\end{array}$ \\
\hline & South Africa & District & $\begin{array}{l}\mathrm{GCD}^{\mathrm{a}} \text { by Moran's I } \\
\mathrm{LCD}^{\mathrm{b}} \text { by Getis-Ord Gi }\end{array}$ & Not done & $\begin{array}{l}\text { Hotspots for multi-morbidity } \\
\text { correlated with the socioeconomic } \\
\text { deprivation }\end{array}$ & $\begin{array}{l}\text { Weimann et al., } \\
2016\end{array}$ \\
\hline & $\begin{array}{l}\text { Lausanne, } \\
\text { Switzerland }\end{array}$ & $\begin{array}{l}\text { District, } \\
\text { neighbour-hood }\end{array}$ & $\begin{array}{l}\mathrm{LCD}^{\mathrm{b}} \text { by } \\
\text { Getis-Ord }\end{array}$ & $\begin{array}{l}\text { Adjusted for } \\
\text { neighbourhood-level } \\
\text { income }\end{array}$ & $\begin{array}{l}\text { Two temporal BMIe-related } \\
\text { clusters. Adjusting for } \\
\text { neighbourhood-level } \\
\text { income attenuated cluster } \\
\text { presence }\end{array}$ & $\begin{array}{l}\text { Joost et al., } \\
2016\end{array}$ \\
\hline & $\begin{array}{l}\text { King County, } \\
\text { USA }\end{array}$ & Neighbour-hood & $\begin{array}{l}\text { LCD }^{b} \text { by LISA and } \\
\text { spatial scan statistics }\end{array}$ & $\begin{array}{l}\text { Adjusted for age, } \\
\text { gender, race, } \\
\text { education, income } \\
\text { and property value }\end{array}$ & $\begin{array}{l}\text { Obesity clusters seen } \\
\text { to attenuate when } \\
\text { adjusted for age, } \\
\text { gender, race, education } \\
\text { and income and to vanish } \\
\text { when adjusted for } \\
\text { neighbourhood residential } \\
\text { property value }\end{array}$ & $\begin{array}{l}\text { Huang et al., } \\
2015\end{array}$ \\
\hline & $\begin{array}{l}\text { King County, } \\
\text { USA }\end{array}$ & ZIP code & Not done & Bivariate analysis & $\begin{array}{l}\text { Property values were the strongest } \\
\text { predictor for area-based obesity } \\
\text { prevalence. Association between } \\
\text { obesity prevalence and ZIP code } \\
\text { contextual characteristics }\end{array}$ & $\begin{array}{l}\text { Drewnowski } \\
\text { et al., } 2007\end{array}$ \\
\hline \multirow[t]{2}{*}{$\begin{array}{l}\text { Residency } \\
\text { (rural or urban) }\end{array}$} & Perú & District & $\begin{array}{l}\text { GCD by Moran's I } \\
\text { LCD by LISA }^{\text {b bis }}\end{array}$ & Not done & $\begin{array}{l}\text { Obesity clusters mostly } \\
\text { seen in coastal } \\
\text { urban districts }\end{array}$ & $\begin{array}{l}\text { Hernandez- } \\
\text { Vasquez } \\
\text { etal. } 2016\end{array}$ \\
\hline & Taiwan & Township & $\begin{array}{l}\text { GCD by Moran's I } \\
\text { LCD by LISA }\end{array}$ & Not done & $\begin{array}{l}\text { Clusters of low utilisation } \\
\text { of cardiovascular drugs } \\
\text { in rural locations }\end{array}$ & $\begin{array}{l}\text { Cheng } \\
\text { et al., } 2011\end{array}$ \\
\hline \multirow[t]{4}{*}{ Climate and pollution } & $\begin{array}{l}\text { Cuiabá and } \\
\text { Várzea Grande, } \\
\text { Brazil }\end{array}$ & Census tract & $\begin{array}{l}\mathrm{LCD}^{\mathrm{b}} \text { by spatial scan } \\
\text { statistics }\end{array}$ & Focus on incidence & $\begin{array}{l}\text { Clusters of mortality, } \\
\text { low humidity, } \\
\text { high-temperatureperiods and } \\
\text { high concentrations of } \mathrm{PM}_{25} \mathrm{f}\end{array}$ & $\begin{array}{l}\text { Rodrigues } \\
\text { et al., } 2015\end{array}$ \\
\hline & Hong Kong & $\begin{array}{l}\text { Small planning } \\
\text { unit }\end{array}$ & $\begin{array}{l}\mathrm{GCD}^{\mathrm{a}} \text { by Moran's I } \\
\mathrm{LCD}^{\mathrm{b}} \text { by LISA }\end{array}$ & Not done & $\begin{array}{l}\text { Spatial overlapping of } \\
\text { clusters of mortality considering } \\
\text { increased and reduced PET's scores }\end{array}$ & $\begin{array}{l}\text { Thach et al., } \\
2015\end{array}$ \\
\hline & $\begin{array}{l}\text { Seoul, } \\
\text { South Korea }\end{array}$ & & $\begin{array}{l}\text { LCD by spatial } \\
\text { scan statistics }\end{array}$ & GWRd & $\begin{array}{l}\text { High CVD mortality coinciding } \\
\text { with high } \mathrm{PM}_{10}{ }^{\mathrm{h}}\end{array}$ & $\begin{array}{l}\text { Lim et al., } \\
2014\end{array}$ \\
\hline & $\begin{array}{l}\text { Yazd Province, } \\
\text { Iran }\end{array}$ & $\begin{array}{l}\text { Fishnet } \\
(2 \times 2 \mathrm{~km} \text { cell size })\end{array}$ & $\begin{array}{l}\text { Hotspot analysis } \\
\text { by ArcGIS }\end{array}$ & Not done & $\begin{array}{l}\text { Overlapping between cluster } \\
\text { of CV event industrial area }\end{array}$ & $\begin{array}{l}\text { Namayande } \\
\text { et al., } 2016\end{array}$ \\
\hline \multirow[t]{5}{*}{$\begin{array}{l}\text { Supportive health } \\
\text { resources }\end{array}$} & $\begin{array}{l}\text { Denver, } \\
\text { USA }\end{array}$ & Census tract & $\begin{array}{l}\text { LCD by } \\
\text { Getis-Ord and LISA }\end{array}$ & Not done & $\begin{array}{l}\text { Overlapping clusters for high } \\
\text { OHCA and low CPRj }\end{array}$ & $\begin{array}{l}\text { Sasson et al., } \\
2012 \\
\text { Nassel et al., } \\
2014\end{array}$ \\
\hline & $\begin{array}{l}\text { Houston } \\
\text { and Travis, } \\
\text { USA }\end{array}$ & $\begin{array}{l}\text { Census block } \\
\text { group }\end{array}$ & $\begin{array}{l}\mathrm{LCD}^{\mathrm{b}} \text { by spatial scan } \\
\text { statistics }\end{array}$ & $\begin{array}{l}\text { Adjusted using } \\
\text { hierarchical logistic } \\
\text { regression models }\end{array}$ & $\begin{array}{l}\text { Clusters of high CPRj after } \\
\text { OHCA }^{\text {d disappear when }} \\
\text { adjusted by individual variables, } \\
\text { such asincome and race }\end{array}$ & $\begin{array}{l}\text { Root et al., } \\
2013\end{array}$ \\
\hline & $\begin{array}{l}\text { Ludhiana, } \\
\text { India }\end{array}$ & Ward & $\begin{array}{l}\text { GCD }^{\text {a }} \text { by Moran's } \\
\text { ILCD }^{\text {b by Getis-Ord }}\end{array}$ & Not done & $\begin{array}{l}\text { Clusters of stroke withpoor } \\
\text { outcomes located in areas without } \\
\text { mayor medical facilities }\end{array}$ & $\begin{array}{l}\text { Pandian } \\
\text { et al., } 2016\end{array}$ \\
\hline & $\begin{array}{l}\text { Michigan, } \\
\text { USA }\end{array}$ & ZIP code & LCD by Getis-Ord & Not done & $\begin{array}{l}\text { Cluster of strict adherence to statin } \\
\text { treatment }\end{array}$ & $\begin{array}{l}\text { Erickson and } \\
\text { Lin, } 2014\end{array}$ \\
\hline & $\begin{array}{l}\text { Michigan, } \\
\text { USA }\end{array}$ & Census tract & LCD by Getis-Ord & Not done & $\begin{array}{l}\text { Cluster of strict adherence to drugs } \\
\text { for CVD treatment, in particular } \\
\text { found around a university hospital }\end{array}$ & $\begin{array}{l}\text { Hoang et al., } \\
2011\end{array}$ \\
\hline
\end{tabular}

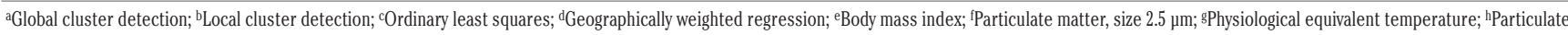
matter, size $10 \mu \mathrm{m}$; iOut-of-hospital cardiac arrest (OHCA); ;Cardiopulmonary resuscitation. 


\section{Factors of importance for cardiovascular disease spatial distribution patterns}

\section{Socioeconomic status}

The nexus between socioeconomic status and CVD is well documented (Backholer et al., 2016). Spatial analysis has provided valuable information for a better understanding of this relation. In Australia, population with high risk for CVD trend to clustering in more disadvantaged areas (Bagheri et al., 2015). In Harris, Texas, geographically weighted regression showed a correlation between high CVD mortality and social deprivation at the neighbourhood level (Ford and Highfield, 2016). Results were similar in a study of an area in Strasbourg, France, where high-risk clusters for myocardial infarction (MI) was seen to accumulate in economically deprived areas despite good access to health amenities (KihalTalantikite et al., 2017). By mapping the level of income and risk of acute myocardial infarction (AMI) hospitalization and mortality during two time intervals (in 1999 and in 2013), a study covering all of USA at the county-level showed that although cardiovascular risk tends to decrease in all income strata, a low earnings level generates latency in this trend (Spatz et al., 2016). Socioeconomic deprivation can promote CVD clustering with other health conditions, like preterm birth for women, since the first condition is a risk factor for the second (Kramer and Williamson, 2013).

Risk analysis show a spatial correlation between deprivation and premature mortality due to diseases of the circulatory system (Juhasz et al., 2010; Boruzs et al., 2016). The risk factors tend to cluster together in socioeconomic disadvantage areas (Weimann et al., 2016), e.g., the BMI clusters found in disadvantaged areas where there is also increased CVDs (Mobley et al., 2004; Joost et al., 2016). Property values refers to probable price of a given property at a given time and is thus related to the regional economy (Coffee et al., 2013; Leonard et al., 2016). High and low obesity clusters were attenuated after adjusting for age, gender, race, education and income; however they disappeared once neighbourhood residential property values and residential density were included (Drewnowski et al., 2007; Huang et al., 2015).

Socioeconomic status can determinate the opportunity of access to health services. Clusters of people dying from heart disease at home before any attempt at transport were observed in areas with lower socioeconomic and household resources (Pathak et al., 2011). Using disease mapping at the district level and risk analysis with rapid inquiry facility (RIF) techniques, one study showed that people living in highly deprived areas showed a low relative frequency of prescriptions of statin treatments (Boruzs et al., 2016).

\section{Education level}

Pedigo and colleagues found that neighbourhoods from eastern Tennessee, USA belonging to a high-risk clusters of stroke and MI mortality tended to have high populations with low education level (Pedigo et al., 2011). A study carried out in Brazil consistent with this finding reports a spatial cluster for ischemic heart disease (IHD) mortality correlating with illiteracy in the study population in question (de Andrade et al., 2013).

\section{Alcohol intake}

The connection between heart disease and high alcohol intake is not uncommon, which fact is in agreement with a study from Chile, where one study region, identified as being ay a high risk for CVD-related deaths associated with alcohol consumption (Castillo-Carniglia et al., 2015). These results are supported by the finding of two clusters in the areas of Valparaíso and Biobio characterized by high alcohol intake; indeed, the alcohol consumption in the latter has been one of the highest in the country for over 45 years (Castillo-Carniglia et al., 2015).

\section{Rural vs urban residency}

Both rural and urban areas have characteristic particularities that may influence the development of CVD. A recent study in Peru highlighted the presence of clusters for obesity in urban children, while in the rural areas the prevalence of obesity was low (Hernandez-Vasquez et al., 2016). A study conducted in Tennessee using the Besag, York and Molliè (BYM) model found rural residency a determinant of for MI and stroke (Odoi and Busingye, 2014). There are geographical clusters among the rural population in Taiwan characterized by underutilization of cardiovascular drugs, which is related to a low presence of specialists in cardiology in some areas (Cheng et al., 2011). Rural living could thus select for inadequate access to health services, hindering the timely management of diseases. In this respect, spatial regression analysis carried out in Taiwan have revealed that mortality related to cold or heat waves is more pronounced in the rural areas due to less access to medical facilities and resources than are available metropolitan areas (Wu et al., 2011).

\section{Environmental influence}

\section{Temperature}

Intermediate-term temperature changes, such as heat and cold waves, can lead to rises immortality by inducing physiologic stress resulting in increased platelet counts, hypercholesterolemia and an enhanced tendency for blood coagulation (Keatinge et al., 1984; Keatinge et al., 1986; Neild et al., 1994). An Australian study based on global and local Moran's I showed increased spatial clustering of CVD during the warmer months, and a weak correlation between AMI and age during the warmer months was detected by Loughnan et al. (2008). A cluster of high general mortality in elderly people, a susceptible group for CVD, was detected after a heat wave in Sydney, Australia (Vaneckova et al., 2010), while Chen et al. (2015) tell us that a heat wave contributed to increased stroke mortality in Nanjing, China. A retrospective study carried out in Cuiabá and Várzea Grande, Brazil, reported a period with higher temperature variations and low humidity coinciding with the appearance of a cluster of high CVD (Rodrigues et al., 2015). However, although there thus seems to be a strong relation between high temperatures and impaired health in CVD patients, the opposite has also been seen, i.e. Roberson et al. (2016) report hospitalization for stroke coupled with a high risk for mortality in winter. The individual energy balance model, discussed by Höppe (1999) and Matzarakis et al. (1999) in the context of a physiological equivalent temperature (PET), may have a bearing on this outcome. PET is defined as the air temperature (in an ambient indoor setting) at which the heat budget of the human body is balanced. This approach enables a comparison of the integral effects of complex thermal conditions outside (not only decided by air temperature, but also by humidity, wind speed, cloud cover, etc.) with the indoor experience. On hot summer days, for example, the PET value may be much higher than the air temperature, while on a windy day in winter considerably lower. Indeed, an ecological study identified a cluster of high mortality correlated with a changed PET score both in cold and warm seasons (Thach et al., 2015). 


\section{Air pollution and noise}

Fine particulate matter in the air, a common problem in modern cities, predisposes the development of respiratory and cardiovascular diseases in urban populace. The correlation between air pollution and CVD is well known (Brunekreef et al., 2009; Dehbi et al., 2016,). $\mathrm{PM}_{2.5}$ and $\mathrm{PM}_{10}$ are particles of different sizes suspended in the air, which are derived from industrial activity, combustion, and diesel emission (Ogundele et al., 2016). Spatial analysis can improve the understanding and detection of pollution emission. Using satellite-derived data for optical $\mathrm{PM}_{2.5}$ detection, it is possible to find spatial CVD clusters in area where there are high levels of pollution confirming that CVD is spatially related to the concentration of particles (Aina et al., 2014; Chen et al., 2016; Weber et al., 2016). High concentrations of both $\mathrm{PM}_{2.5}$ and $\mathrm{PM}_{10}$ have been shown to be spatially correlated to mortality due to CVDs (Tonne et al., 2009; Lim et al., 2014; Rodrigues et al., 2015), and clusters of AMI events close to industry installations, specifically steel industry, have been reported (Namayande et al., 2016).

A study carried out in Barcelona, Spain suggests that areas with high traffic noise can be just as dangerous as pollution for MI mortality. In addition, increased OLS indicate a connection between noise and conditions, such as Type II diabetes mellitus in men and mortality due to hypertension in women (Barcelo et al., 2016). In France, an ecological study showed a spatial correlation between mortality due to IHD, MI, and stroke mentioning 161 communes exposed to high noise levels related to the three main airports in the country (Evrard et al., 2015).

\section{Water}

Ecological studies are useful to detect neighbourhood determinants with impact on health. For example, the quality of drinking water has been shown to influence the progress of CVD. The number of cardiovascular, coronary and cerebrovascular disease increased in municipalities with high arsenic concentrations in the drinking water (Medrano et al., 2010), and an association between arsenic water content and stroke admissions in a analysis based on zip codes and binomial regression models (Lisabeth et al., 2010).

\section{Support from health-related resources}

\section{Bystander cardiopulmonary resuscitation}

Cardiopulmonary resuscitation (CPR) performed by a bystander (B-CPR) is defined as CPR performed by any person who isnot part of the organized emergency-response system in a community (Bradley and Rea, 2011). The prevalence of this knowledge in a population speaks of its level of development (Bradley and Rea, 2011). Spatial analysis has been useful to identify and improve the management of this technique in the population (Nassel et al., 2014). Taking in account clusters of out-of-hospital cardiac arrest (OHCA) and the prevalence of B-CPR in a community, populations at high risk for OHCA can be estimated (Lerner et al., 2005; Sasson et al., 2010; Sasson et al., 2012; Nassel et al., 2014). Nassel and colleagues (2014) have proposed a standardized approach to improve the detection of such populations using three different spatial analytic methods. When two out of three of these methods identify a location with high OHCA incidence and low B-CPR, this location is definitely at high risk. Income is an important determinant of the prevalence of B-CPR as OHCA victims in census tracts characterized by high income are more likely to receive B-CPR than others (Sasson et al., 2011;
Root et al., 2013). This disproportion is increased among African American neighbourhoods, which are therefore promising targets for community-based interventions at the neighbourhood level.

\section{Access to health resources}

Swift and easy access to health establishments can determinate outcome and adherence to treatment with regard to the CVDs. Ecological analyses based on spatial approaches support prioritizing target areas that require improved health service coverage. Using descriptive mapping it is possible characterize travel time and population coverage for cardiac interventional services, enabling direct, visual detection of areas (or populations) with lowlevel access (Graves, 2011; Clark et al., 2012). Mapping has also has been used to identify areas with poor ambulance response times (Earnest et al., 2012). Principal component analysis (PCA) allows condensing variables related to a given phenomenon and sorting them into a hierarchal diagram. Using this technique to combine variables associated with disease burdens and access to health services, Hames et al. (2016) detected areas of high medical vulnerability by GIS mapping and $\mathrm{z}$ scoring at the census tract level. In addition to mapping, the study of interaction with social vulnerability by bivariate analysis proved useful for the detection of vulnerable areas for an old-people group among the general population (Hames et al., 2016). However, the situation can sometimes be more complex as revealed by a study conducted in Denmark where the existence of a strong correlation between individuals with a low AMI mortality rate and personal initiative was revealed (Ersboll et al., 2016). While a fatal AMI was seen among only $12.0 \%$ of individuals having asked for a medical check-up the year before the AMI, the outcome was fatal in as much as $78 \%$ in those who had not. In this study, a high population ratio to practicing doctors (GP) or a long distance to a GP could not explain the increased odds of a fatal outcome of AMI in individuals without such contact. In the Indian city of Ludhiana, on the other hand, clusters of poor outcome after stroke have been found to occur in locations far from major medical facilities (Pandian et al., 2016).

Geographical and socio-economic factors can determine access to health services. Both the personal health state, car ownership and distance to service are determinates for predicting access to health services. GWR was useful to weigh the effects of these variables on health access indicating locations where the predictive strength of the independent variables was higher or lower than the global trend (Comber et al., 2011). Spatial analysis has also been a valuable tool in the study of health resource distribution, for example when identifying population at risk by the multicriterion two-step floating catchment area (MC2SFCA) method, which enables measuring healthcare accessibility, thus facilitating the allocation of automated external defibrillators (Lin et al., 2016). Indeed, GIS plays a an important role in the development of algorithms for this purpose as well as for improving cardiac diagnostic resources (Kaffash-Charandabi et al., 2015; Ferguson et al., 2016). In England, ecological studies based on mapping and detection of clusters for the proportion of observed medical diagnoses have been useful for the determination of areas where CVDs are under-diagnosed (Soljak et al., 2011). The use of GWR to assess whether a linear regression relationship between observed and expected prevalence of CVD exist allowed the detection of areas where more general practitioners would be needed.

\section{Adherence to prescribed medical treatment}

Spatial analyses of people on medicines for CVD has showed clustering for drug adherence (Cheng et al., 2011; Erickson and 
Lin, 2014). By application of GIS technology, Hoang et al. (2011) found a cluster of strong adherence for acute coronary syndrome treatment round a university hospital, and White et al. (2016) described a cluster of low prevalence for hypertension, which was related to the presence of a physician known to provide adequate primary health care.

\section{Conclusions}

Studies that use spatial analysis in health have been useful to understand the implication of environmental factors in the development of CVD. To obtain reliable results, it is important to use adequate statistical and geospatial analysis tools, as well as an adequate definition of the geographical units used. In the spatial distribution of CVD, the socioeconomic level, the level of urbanity and education of the population have an important influence. These variables determine the level of access and link to health services. Environmental variables, such as temperature, humidity and contamination also determine the distribution of CVD. In this way, the application of spatial study helps to recognize particularly vulnerable areas where intervention can take place facilitating the allocation of health resources and/or applying prevention policies for these diseases.

\section{References}

Aamodt G, Samuelsen SO, Skrondal A, 2006. A simulation study of three methods for detecting disease clusters. Int J Health Geogr 5:15.

Ahmadi A, Soori H, Mehrabi Y, Etemad K, 2015. Spatial analysis of myocardial infarction in Iran: National report from the Iranian myocardial infarction registry. J Res Med Sci 20:4349.

Aina YA, van der Merwe JH, Alshuwaikhat HM, 2014. Spatial and temporal variations of satellite-derived multi-year particulate data of Saudi Arabia: an exploratory analysis. Int J Environ Res Public Health 11:11152-66.

Anno S, Imaoka K, Tadono T, Igarashi T, Sivaganesh S, Kannathasan S, Kumaran V, Surendran SN, 2015. Space-time clustering characteristics of dengue based on ecological, socioeconomic and demographic factors in northern Sri Lanka. Geospat Health 10:215-22.

Anselin L, 1995. Local indicators of spatial association - LISA. Geogr Anal 27:93-115.

Arsenault J, Michel P, Berke O, Ravel A, Gosselin P, 2013. How to choose geographical units in ecological studies: proposal and application to campylobacteriosis. Spat Spatiotemporal Epidemiol 7:11-24.

Backholer K, Peters SAE, Bots SH, Peeters A, Huxley RR, Woodward M, 2017. Sex differences in the relationship between socioeconomic status and cardiovascular disease: a systematic review and meta-analysis. J Epidemiol Community Health 71:550-7.

Bagheri N, Gilmour B, Mcrae I, Konings P, Dawda P, Del Fante P, Van Weel C, 2015. Community cardiovascular disease risk from cross-sectional general practice clinical data: a spatial analysis. Prev Chronic Dis 12:140379.

Bailey TC, Gatrell AC, 1995. Interactive spatial data analysis.
Longman Scientific \& Technical.

Barcelo MA, Varga D, Tobias A, Diaz J, Linares C, Saez M, 2016. Long term effects of traffic noise on mortality in the city of Barcelona, 2004-2007. Environ Res 147:193-206.

Bergquist R, 2017. Climate and the distribution of vector-borne diseases: what's in store? Geospat Health 12:1-2.

Boruzs K, Juhasz A, Nagy C, Adany R Biro K, 2016. Relationship between statin utilization and socioeconomic deprivation in Hungary. Front Pharmacol 7:66.

Bradley SM, Rea TD, 2011. Improving bystander cardiopulmonary resuscitation. Curr Opin Crit Care 17:219-24.

Brunekreef B, Beelen R, Hoek G, Schouten L, Bausch-Goldbohm $\mathrm{S}$, Fischer P, Armstrong B, Hughes E, Jerrett M, Van Den Brandt P, 2009. Effects of long-term exposure to traffic-related air pollution on respiratory and cardiovascular mortality in the Netherlands: the NLCS-AIR study. Res Rep Health Eff Inst 139:5-71.

Brunsdon C, Fotheringham AS, Charlton ME, 1996. Geographically weighted regression: a method for exploring spatial nonstationarity. Geogr Anal 28:281-98.

Castillo-Carniglia A, Kaufman JS, Pino P, 2015. Geographical distribution of alcohol-attributable mortality in Chile: a Bayesian spatial analysis. Addict Behav 42:207-15.

Caswell JM, 2016. Exploring spatial trends in Canadian incidence of hospitalization due to myocardial infarction with additional determinants of health. Public Health 140:136-143.

Chen H, Burnett RT, Copes R, Kwong JC, Villeneuve PJ, Goldberg MS, Brook RD, van Donkelaar A, Jerrett M, Martin RV, Brook JR, Kopp A, Tu JV, 2016. Ambient fine particulate matter and mortality among survivors of myocardial infarction: population-based cohort study. Environ Health Perspect 124:1421-8.

Chen K, Huang L, Zhou L, Ma Z, Bi J, Li T, 2015. Spatial analysis of the effect of the 2010 heat wave on stroke mortality in Nanjing, China. Sci Rep 5:10816.

Cheng CL, Chen YC, Liu TH, Yang YH, 2011. Using spatial analysis to demonstrate the heterogeneity of the cardiovascular drug-prescribing pattern in Taiwan. BMC Public Health 11:1471-2458.

Clark RA, Coffee N, Turner D, Eckert KA, Van Gaans D, Wilkinson D, Stewart S, Tonkin AM, 2012. Application of geographic modeling techniques to quantify spatial access to health services before and after an acute cardiac event: the Cardiac Accessibility and Remoteness Index for Australia (ARIA) project. Circulation 125:2006-2014.

Coffee NT, Lockwood T, Hugo G, Paquet C, Howard NJ, Daniel M, 2013. Relative residential property value as a socio-economic status indicator for health research. Int J Health Geogr 12:12-22.

Comber AJ, Brunsdon C, Radburn R, 2011. A spatial analysis of variations in health access: linking geography, socio-economic status and access perceptions. Int J Health Geogr 10:1.

Cunningham-Myrie CA, Theall KP, Younger NO, Mabile EA, Tulloch-Reid MK, Francis DK, McFarlane SR, GordonStrachan GM, Wilks RJ, 2015. Associations between neighborhood effects and physical activity, obesity, and diabetes: the Jamaica Health and Lifestyle Survey 2008. J Clin Epidemiol 68:970-8.

De Andrade L, Zanini V, Batilana AP, De Carvalho EC, Pietrobon R, Nihei OK, De Barros Carvalho MD, 2013. Regional disparities in mortality after ischemic heart disease in a Brazilian state from 2006 to 2010. PLoS One 8:19. 
Dehbi HM, Blangiardo M, Gulliver J, Fecht D, De Hoogh K, AlKanaani Z, Tillin T, Hardy R, Chaturvedi N, Hansell AL, 2016. Air pollution and cardiovascular mortality with over 25 years follow-up: A combined analysis of two British cohorts. Environ Int 7:30950-3.

Drewnowski A, Rehm CD, Solet D, 2007. Disparities in obesity rates: analysis by ZIP code area. Soc Sci Med 65:2458-63.

Earnest A, Hock Ong ME, Shahidah N, Min NGW, Foo C, Nott DJ, 2012. Spatial analysis of ambulance response times related to prehospital cardiac arrests in the city-state of Singapore. Prehosp Emerg Care 16:256-65.

Erickson SR, Lin YN. 2014. Geospatial analysis of statin adherence using pharmacy claims data in the state of Michigan. J Manag Care Spec Pharm 20:1208-15.

Ersboll AK, Kjaerulff TM, Bihrmann K, Schipperijn J, Gislason G, Larsen M, 2016. Geographical variation in a fatal outcome of acute myocardial infarction and association with contact to a general practitioner. Spat Spatiotemporal Epidemiol 19:60-9.

Evrard AS, Bouaoun L, Champelovier P, Lambert J, Laumon B, 2015. Does exposure to aircraft noise increase the mortality from cardiovascular disease in the population living in the vicinity of airports? Results of an ecological study in France. Noise Health 17:328-36.

Exeter D, Flowerdew R, Boyle P, 2007. Policy implications of pockets of deprivation in Scotland. GIS Evid Based Policy Making 95.

Exeter DJ, Zhao J, Hanham G, Grey C, Wells S, Kerr A, 2014. Construction and use of mapping techniques to describe the geographical distribution of medication dispensing for the secondary prevention of atherosclerotic CVD in New Zealand: VIEW-2. N Z Med J 127:70-80.

Ferguson WJ, Kemp K, Kost G, 2016. Using a geographic information system to enhance patient access to point-of-care diagnostics in a limited-resource setting. Int $\mathrm{J}$ Health Geogr 15:016-0037.

Ford MM, Highfield LD, 2016. Exploring the spatial association between social deprivation and cardiovascular disease mortality at the neighborhood level. PLoS One 11.

Getis A, Ord JK, 1992. The analysis of spatial association by use of distance statistics. Geogr Anal 24:189-206.

Gohari K, Parsaeian M, Sheidaei A, Rahimzadeh S, Baghestani AR, Pourhoseinghol MA, Pazhuheian F, Saeedi Moghaddam S, Mansouri A, Naderimagham S, Kavousi A, Farzadfar F, 2015. Equity chasm in megacities: five leading causes of death in Tehran. Arch Iran Med 18:622-8.

Gomez-Barroso D, Prieto-Flores ME, Mellado San Gavino A, Moreno Jimenez A, 2015. Spatial analysis of mortality from cardiovascular diseases in Madrid City, Spain. Rev Esp Salud Publica 89:27-37.

Gómez-Rubio V, Ferrándiz-Ferragud J, López-Quílez A, 2005. Detecting clusters of disease with R. J Geogr Syst 7:189-206.

Graham AJ, Atkinson PM, Danson FM, 2004. Spatial analysis for epidemiology. Acta Trop 91:219-25.

Graves BA, 2011. Geographic analysis of cardiac interventional services in Alabama. J Cardio Nurs 26:E1-E11.

Griffith DA, 1987. Spatial autocorrelation. A Primer Washington DC: Association of American Geographers.

Hames E, Stoler J, Emrich CT, Tewary S, Pandya N, 2017. A GIS approach to identifying socially and medically vulnerable older adult populations in South Florida. Gerontologist 57;1133-41.
Hastie T, Tibshirani R, 1986. Generalized additive models. Statist Sci 297-310.

Hernandez-Vasquez A, Bendezu-Quispe G, Diaz-Seijas D, Santero M, Minckas N, Azanedo D, Antiporta DA, 2016. Spatial analysis of childhood obesity and overweight in Peru, 2014. Rev Peru Med Exp Salud Publica 33:489-97.

Hoang C, Kolenic G, Kline-Rogers E, Eagle KA, Erickson SR, 2011. Mapping geographic areas of high and low drug adherence in patients prescribed continuing treatment for acute coronary syndrome after discharge. Pharmacotherapy 31:927-33.

Höppe P, 1999. The physiological equivalent temperature-a universal index for the biometeorological assessment of the thermal environment. Int J Biometeorol 43:71-5.

Huang R, Moudon AV, Cook AJ, Drewnowski A, 2015. The spatial clustering of obesity: does the built environment matter? J Hum Nutr Diet 28:604-12.

Jacquez GM, 2008. Spatial cluster analysis. The handbook of geographic information science 395:416.

Jerrett M, Burnett R, Goldberg M, Sears M, Krewski D, Catalan R, Kanaroglou P, Giovis C, Finkelstein N, 2003. Spatial analysis for environmental health research: concepts, methods, and examples. J Toxicol Environ Health Part A 66:1783-810.

Jiwa M, Gudes O, Varhol R, Mullan N, 2015. Impact of geography on the control of type 2 diabetes mellitus: a review of geocoded clinical data from general practice. BMJ Open 5:e009504.

Joost S, Duruz S, Marques-Vidal P, 2016. Persistent spatial clusters of high body mass index in a Swiss urban population as revealed by the 5-year GeoCoLaus longitudinal study. BMJ Open 6:e010145.

Juhasz A, Nagy C, Paldy A, Beale L, 2010. Development of a Deprivation Index and its relation to premature mortality due to diseases of the circulatory system in Hungary, 1998-2004. Soc Sci Med 70:1342-9.

Kaffash-Charandabi N, Sadeghi-Niaraki A, Park DK, 2015. Using a Combined Platform of Swarm Intelligence Algorithms and GIS to Provide Land Suitability Maps for Locating Cardiac Rehabilitation Defibrillators. Iran J Public Health 44:1072-83.

Keatinge WR, Coleshaw SR, Cotter F, Mattock M, Murphy M, Chelliah R, 1984. Increases in platelet and red cell counts, blood viscosity, and arterial pressure during mild surface cooling: factors in mortality from coronary and cerebral thrombosis in winter. Br Med J 289:1405-8.

Keatinge WR, Coleshaw SR, Easton JC, Cotter F, Mattock MB, Chelliah R, 1986. Increased platelet and red cell counts, blood viscosity, and plasma cholesterol levels during heat stress, and mortality from coronary and cerebral thrombosis. Am J Med 81:795-800.

Kihal-Talantikite W, Weber C, Pedrono G, Segala C, Arveiler D, Sabel CE, Deguen S, Bard D, 2017. Developing a data-driven spatial approach to assessment of neighbourhood influences on the spatial distribution of myocardial infarction. Int $\mathrm{J}$ Health Geogr 16:017-0094.

Kjaerulff TM, Ersboll AK, Gislason G, Schipperijn J, 2016. Geographical clustering of incident acute myocardial infarction in Denmark: A spatial analysis approach. Spat Spatiotemporal Epidemiol 19:46-59.

Kramer Mr, Williamson R, 2013. Multivariate Bayesian spatial model of preterm birth and cardiovascular disease among Georgia women: Evidence for life course social determinants of health. Spat Spatiotemporal Epidemiol 6:25-35.

Kulldorff M, 1997. A spatial scan statistic. Commun Stat Theory 
Methods 26:1481-96.

Leonard T, Powell-Wiley TM, Ayers C, Murdoch JC, Yin W, Pruitt SL, 2016. Property values as a measure of neighborhoods: an application of hedonic price theory. Epidemiology 27:518-24.

Lerner EB, Fairbanks RJ, Shah MN, 2005. Identification of out-ofhospital cardiac arrest clusters using a geographic information system. Acad Emerg Med 12:81-4.

Levine N, Kim KE, Nitz LH, 1995. Spatial analysis of Honolulu motor vehicle crashes: II. Zonal generators. Accident Anal Prevent 27:675-85.

Lim YR, Bae HJ, Lim YH, Yu S, Kim GB, Cho YS, 2014. Spatial analysis of PM10 and cardiovascular mortality in the Seoul metropolitan area. Environ Health Toxicol 31.

Lin BC, Chen CW, Chen CC, Kuo CL, Fan IC, Ho CK, Liu IC, Chan TC, 2016. Spatial decision on allocating automated external defibrillators (AED) in communities by multi-criterion two-step floating catchment area (MC2SFCA). Int J Health Geogr 15:016-0046.

Lisabeth LD, Ahn HJ, Chen JJ, Sealy-Jefferson S, Burke JF, Meliker JR, 2010. Arsenic in drinking water and stroke hospitalizations in Michigan. Stroke 41:2499-504.

Lorant V, Thomas I, Deliege D, Tonglet R, 2001. Deprivation and mortality: the implications of spatial autocorrelation for health resources allocation. Soc Sci Med 53:1711-9.

Loughnan ME, Nicholls N, Tapper NJ, 2008. Demographic, seasonal, and spatial differences in acute myocardial infarction admissions to hospital in Melbourne Australia. Int J Health Geogr 7:7-42.

Martinez AN, Mobley LR, Lorvick J, Novak SP, Lopez AM, Kral $\mathrm{AH}, 2014$. Spatial analysis of HIV positive injection drug users in San Francisco, 1987 to 2005. Int J Environ Res Pub Health 11:3937-55.

Martínez Bascuñán M, Rojas Quezada C, 2017. Geographically weighted regression for modelling the accessibility to the public hospital network in Concepción Metropolitan Area, Chile. Geospat Health 11:451.

Matzarakis A, Mayer H, Iziomon MG, 1999. Applications of a universal thermal index: physiological equivalent temperature. Int J Biometeorol 43:76-84.

Medrano MJ, Boix R, Pastor-Barriuso R, Palau M, Damián J, Ramis R, Del Barrio JL, Navas-Acien A, 2010. Arsenic in public water supplies and cardiovascular mortality in Spain. Environ Res 110:448-54.

Mobley LR, Finkelstein EA, Khavjou OA, Will JC, 2004. Spatial analysis of body mass index and smoking behavior among WISEWOMAN participants. J Womens Health 13:519-28.

Moran PA, 1948. The interpretation of statistical maps. J Royal Statist Soc Series B (Methodological) 10:243-51.

Namayande MS, Nejadkoorki F, Namayande SM, Dehghan H, 2016. Spatial hotspot analysis of acute myocardial infarction events in an urban population: a correlation study of health problems and industrial installation. Iran J Pub Health 45:94101.

Nassel AF, Root ED, Haukoos JS, Mcvaney K, Colwell C, Robinson J, Eigel B, Magid DJ, Sasson C, 2014. Multiple cluster analysis for the identification of high-risk census tracts for out-of-hospital cardiac arrest (OHCA) in Denver, Colorado. Resuscitation 85:1667-73.

Neild PJ, Syndercombe-Court D, Keatinge WR, Donaldson GC, Mattock M, Caunce M, 1994. Cold-induced increases in erythrocyte count, plasma cholesterol and plasma fibrinogen of elderly people without a comparable rise in protein $\mathrm{C}$ or factor X. Clin Sci 86:43-8.

Nunes KV, Neves SM, Ignotti E, 2013. Mortality due to diseases of the circulatory system among the elderly population in Brazilian Amazon: temporal and spatial analysis. Rev Bras Epidemiol 16:838-48.

Odoi A, Busingye D, 2014. Neighborhood geographic disparities in heart attack and stroke mortality: comparison of global and local modeling approaches. Spat Spatiotemporal Epidemiol 11:109-23.

Ogundele LT, Owoade OK, Olise FS, Hopke PK, 2016. Source identification and apportionment of PM2.5 and PM2.5-10 in iron and steel scrap smelting factory environment using PMF, PCFA and UNMIX receptor models. Environ Monit Assess 188:016-5585.

Oliveira AL, Cabral AJ, Mendes JM, Martins MR, Cabral P, 2015. Spatiotemporal analysis of the relationship between socioeconomic factors and stroke in the Portuguese mainland population under 65 years old. Geospat Health 10:365.

Openshaw S, Charlton M, Wymer C, Craft A, 1987. A mark 1 geographical analysis machine for the automated analysis of point data sets. Int J Geogr Info Syst 1:335-58.

Osypuk TL, Galea S, 2007. What level macro? Choosing appropriate levels to assess how place influences population health. In: Galea S, ed. Macrosocial determinants of population health. New York, NY: Springer; pp 399-435.

Pandian JD, Singh G, Kaur P, Bansal R, Paul BS, Singla M, Singh S, Samue CJ, Verma SJ, Moodbidri P, Mehmi G, Sharma A, Arora OP, Dhanuka AK, Sobti MK, Sehgal H, Kaur M, Grewal SS, Jhawar SS, Shadangi TN, Arora T, Saxena A, Sachdeva G, Gill JS, Brar RS, Gill A, Bakshi SS, Pawar SS, Singh G, Sikka P, Litoria PK, Sharma M, 2016. Incidence, short-term outcome, and spatial distribution of stroke patients in Ludhiana, India. Neurology 86: 425-33.

Park SY, Kwak JM, Seo EW, Lee KS, 2016. Spatial analysis of the regional variation of hypertensive disease mortality and its socio-economic correlates in South Korea. Geospat Health. $11: 182-9$.

Paquet C, Chaix B, Howard NJ, Coffee NT, Adams RJ, Taylor AW, Thomas F, Daniel M. 2016. Geographic clustering of cardiometabolic risk factors in metropolitan centres in France and Australia. Int J Environ Res Public Health 13.

Pathak EB, Reader S, Tanner JP, Casper ML, 2011. Spatial clustering of non-transported cardiac decedents: the results of a point pattern analysis and an inquiry into social environmental correlates. Int J Health Geogr 10:10-46.

Pedigo A, Aldrich T, Odoi A, 2011. Neighborhood disparities in stroke and myocardial infarction mortality: a GIS and spatial scan statistics approach. BMC Public Health 11:1471-2458.

Rezaeian M, 2009. Application of geographical sciences and technologies to investigate health problems in the Eastern Mediterranean Region. East Mediterr Health J 15:1564-9.

Rezaeian M, Dunn G, St Leger S, Appleby L, 2006. Ecological association between suicide rates and indices of deprivation in the north west region of England: the importance of the size of the administrative unit. J Epidemiol Commun Health 60:95661.

Rezaeian M, Dunn G, St Leger S, Appleby L, 2007. Geographical epidemiology, spatial analysis and geographical information systems: a multidisciplinary glossary. J Epidemiol Community Health 61:98-102. 
Roberson S, Dutton M, Macdonald M, Odoi A, 2016. Does place of residence or time of year affect the risk of stroke hospitalization and death? A descriptive spatial and temporal epidemiologic study. PLoS One 11.

Rodrigues PC, Santos ES, Ignotti E, Hacon SS, 2015. Space-time analysis to identify areas at risk of mortality from cardiovascular disease. Biomed Res Int 841645:4.

Root ED, Gonzales L, Persse DE, Hinchey PR, Mcnally B, Sasson C, 2013. A tale of two cities: the role of neighborhood socioeconomic status in spatial clustering of bystander CPR in Austin and Houston. Resuscitation 84:752-9.

Sasson C, Cudnik MT, Nassel A, Semple H, Magid DJ, Sayre M, Keseg D, Haukoos JS, Warden CR, 2012. Identifying high-risk geographic areas for cardiac arrest using three methods for cluster analysis. Acad Emerg Med 19:39-146.

Sasson C, Keirns CC, Smith D, Sayre M, Macy M, Meurer W, Mcnally BF, Kellermann AL, Iwashyna TJ, 2010. Small area variations in out-of-hospital cardiac arrest: does the neighborhood matter? Ann Intern Med 153:19-22.

Sasson C, Keirns CC, Smith DM, Sayre MR, Macy ML, Meurer WJ, Mcnally BF, Kellermann AL, Iwashyna TJ, 2011. Examining the contextual effects of neighborhood on out-ofhospital cardiac arrest and the provision of bystander cardiopulmonary resuscitation. Resuscitation 82:674-9.

Soares PA, Nascimento LF, 2010. Spatial analysis of hospitalization for heart diseases in Vale do Paraiba. Arq Bras Cardiol 94:747-53.

Sofianopoulou E, Pless-Mulloli T, Rushton S, 2006. Use of spatial autocorrelation to investigate clustering of health deprivation. Epidemiology 17:S95.

Soljak M, Samarasundera E, Indulkar T, Walford H, Majeed A, 2011. Variations in cardiovascular disease under-diagnosis in England: national cross-sectional spatial analysis. BMC Cardiovasc Disord 11:1471-2261.

Spatz ES, Beckman AL, Wang Y, Desai NR, Krumholz HM, 2016. Geographic variation in trends and disparities in acute myocardial infarction hospitalization and mortality by income levels, 1999-2013. JAMA Cardiol 1:255-65.

Talbott EO, Rager JR, Brink LL, Benson SM, Bilonick RA, Wu WC, Han YY, 2013. Trends in acute myocardial infarction hospitalization rates for US States in the CDC tracking network. PLoS One 8.

Tamura K, Puett RC, Hart JE, Starnes HA, Laden F, Troped PJ, 2014. Spatial clustering of physical activity and obesity in relation to built environment factors among older women in three
U.S. states. BMC Public Health 14:1471-2458.

Thach TQ, Zheng Q, Lai PC, Wong PP, Chau PY, Jahn HJ, Plass D, Katzschner L, Kraemer A, Wong CM, 2015. Assessing spatial associations between thermal stress and mortality in Hong Kong: a small-area ecological study. Sci Total Environ 502:666-72.

Tonne C, Yanosky J, Gryparis A, Melly S, Mittleman M, Goldberg R, Von Klot S, Schwartz J, 2009. Traffic particles and occurrence of acute myocardial infarction: a case-control analysis. Occup Environ Med 66:797-804.

Van Rheenen S, Watson TW, Alexander S, Hill MD, 2015. An analysis of spatial clustering of stroke types, in-hospital mortality, and reported risk factors in Alberta, Canada, using geographic information systems. Can J Neurol Sci 42:299-309.

Vaneckova P, Beggs PJ, Jacobson CR, 2010. Spatial analysis of heat-related mortality among the elderly between 1993 and 2004 in Sydney, Australia. Soc Sci Med 70:293-304.

Wang Y, Du Q, Ren F, Liang S, Lin DN, Tian Q, Chen Y, Li JJ, 2014a. Spatio-temporal variation and prediction of ischemic heart disease hospitalizations in Shenzhen, China. Int J Environ Res Public Health 11:4799-824.

Wang Z, Du Q, Liang S, Nie K, Lin DN, Chen Y, Li JJ, 2014b. Analysis of the spatial variation of hospitalization admissions for hypertension disease in Shenzhen, China. Int J Environ Res Public Health 11:713-33.

Weber SA, Insaf TZ, Hall ES, Talbot TO, Huff AK, 2016. Assessing the impact of fine particulate matter (PM2.5) on respiratory-cardiovascular chronic diseases in the New York City Metropolitan area using Hierarchical Bayesian Model estimates. Environ Res 151:399-409.

Weimann A, Dai D, Oni T, 2016. A cross-sectional and spatial analysis of the prevalence of multimorbidity and its association with socioeconomic disadvantage in South Africa: A comparison between 2008 and 2012. Soc Sci Med 163:144-56.

White K, Stewart JE, Lopez-Defede A, Wilkerson RC, 2016. Small-area variation in hypertension prevalence among black and white medicaid enrollees. Ethn Dis 26:331-8.

Wu PC, Lin CY, Lung SC, Guo HR, Chou CH, Su HJ, 2011. Cardiovascular mortality during heat and cold events: determinants of regional vulnerability in Taiwan. Occup Environ Med 68:525-30.

Zhu G, Xu X, Ma Z, Xu L, Porter JH, 2012. Spatial dynamics and zoning of coastal land-use change along Bohai Bay, China, during 1979-2008. J Coastal Res 28:1186-96. 